\title{
THE PROTESTANT FISCAL ETHIC: RELIGIOUS CONFESSION AND EURO SKEPTICISM IN GERMANY
}

\author{
ADRIAN CHADI and MATTHIAS KRAPF*
}

\begin{abstract}
During the European sovereign debt crisis, most countries that ran into fiscal trouble had Catholic majorities, whereas countries with Protestant majorities were able to avoid fiscal problems. We find that Christian-conservative members of the German parliament from constituencies with higher shares of Protestants were more likely to vote against a third bailout for Greece. Survey data show that views on the euro differ between German Protestants and non-Protestants at the individual level, too. Among Protestants, concerns about the euro have, compared to non-Protestants, increased during the crisis. We show that this increase in concern is linked to a reduction of Protestants' subjective well-being. We use the timing of survey interviews and news events in 2011 to account for the endogeneity of euro concerns. Emphasis on moral hazard concerns in Protestant theology may, thus, still shape economic preferences. (JEL D72, E00, I31, Z12)
\end{abstract}

\section{INTRODUCTION}

Since the beginning of the sovereign debt crisis, Europe has been economically divided along religious lines. Many of the countries with large fiscal problems have Catholic majorities, whereas among the countries that have been doing better, Germany and the Netherlands have traditionally been split between Protestants and Catholics, Finland is Lutheran Protestant, while only Austria is predominantly Catholic. ${ }^{1}$ In this paper, we study whether German support for eurozone bailouts differs along religious lines. We present several pieces of evidence in favor of this.

${ }^{*}$ We are grateful to Benito Arruñanda, Marius Brülhart, Sam Butterick, Daniel Hamermesh, Niklas Potrafke, Dominic Rohner, Heinrich Ursprung, Hans-Joachim Voth, and two anonymous referees, as well as to participants of presentations at Université de Lausanne, at Journées LAGV in Aixen-Provence, at the UPF Workshop on Institutions and Organizations in Barcelona, and at the VfS Meeting in Münster for helpful comments and suggestions.

Chadi: Dr. rer. pol., Department of Economics, IAAEU-Trier University, Trier 54286, Germany. Phone +49 651201 4774, Fax +49651 201 4742, E-mail chadi@iaaeu.de

Krapf: Dr. rer. pol., WWZ Wirtschaftswissenschaftliche Fakultät, University of Basel, Basel 4002, Switzerland. Phone +41 $61 \quad 207 \quad 58 \quad 29$, E-mail matthias.krapf@unibas.ch

1. The idea that religion, in particular cultural differences between Protestants and non-Protestants, might play a role in the context of the euro crisis has been discussed before in various media outlets (Ankenbrand 2013, 2014; Bowlby 2012; Priluck 2015).
The first piece of evidence consists of an analysis of the vote on a third bailout for Greece in the German parliament on August 19, 2015. While this proposal was supported by the German government, there was substantial opposition from within Chancellor Angela Merkel's own Christian-conservative CDU/CSU faction (Christian Democratic Union of Germany and Christian Social Union in Bavaria). In the end, 63 out of $311 \mathrm{CDU} / \mathrm{CSU}$ members of the German parliament (MPs) refused to follow the Chancellor in supporting continued financial assistance for Greece. We show that voting against the third bailout was positively related to the share of Protestants in an MP's constituency. Using data from the 2003 and 2011 waves of the German Socio-Economic Panel (SOEP), we then investigate the link between religious denomination and attitudes toward the euro in the broader population. Protestants displayed positive attitudes toward the euro in 2003, but have changed their

\section{ABBREVIATIONS}

CDU: Christian Democratic Union

CSU: Christian Social Union

EVS: European Values Survey GDP: Gross Domestic Product IV: Instrumental Variable MPs: Members of Parliament OLS: Ordinary Least Squares SOEP: Socio-Economic Panel SPD: Social Democrat Party 
views during the euro crisis. We substantiate our findings with evidence on people's subjective well-being. We use variation in media coverage prior to the time of the interview to show that subjective well-being of German Protestants is reduced by exogenous news related to the euro crisis, whereas the well-being of non-Protestants remains largely unaffected.

The paper proceeds as follows. After a brief overview of the literatures to which our study contributes in Section II, Section III describes our empirical approach. Section IV displays the empirical analysis, which suggests that German Protestants tended to be more critical of the common currency and more opposed to bailouts. In Section V, we discuss these empirical results. Section VI concludes.

\section{LITERATURE}

Recent research shows adverse effects of the financial and banking crises on the happiness of Americans (Deaton 2012) and Europeans (Montagnoli and Moro 2014). While, for example, during the financial crisis of 2008/2009, unemployment went up and incomes went down, the German economy did relatively well during the euro crisis in 2011 (Dustmann et al. 2014). The euro crisis led to increased uncertainty about future economic conditions and fiscal transfers toward Greece and Portugal, but low interest rates and capital inflows from struggling economies in the euro zone helped the German economy recover from the financial crisis. In contrast to the financial crisis, the euro crisis had only a perceived rather than an actual adverse effect on the German population at large. Still, there is evidence for dissent toward policies related to the euro crisis, both in politics and in the German public, as demonstrated by the rise of the antieuro party Alternative für Deutschland. Notably, while there is research on dissent in parliaments for both the United States (Mian, Sufi, and Trebbi 2010) and for Germany (Kauder, Potrafke, and Riem 2015), religion has not, thus far, played a role in this discussion of parliamentary voting behavior.

A literature has emerged, which has linked the euro crisis to cultural differences across euro member countries (Guiso, Herrera, and Morelli 2016), and which has tried to define optimal arrangements for European institutions when member states are heterogeneous (Boffa, Piolatto, and Ponzetto 2016). We link this with another recent literature, which emphasizes that individual experiences (Ehrmann and Tzamourani 2012; Giuliano and Spilimbergo 2014; Malmendier and Nagel 2011) and even events that happened hundreds of years ago (Guiso, Sapienza, and Zingales 2006, 2016; Nunn 2009; Voigtländer and Voth 2012) shape economic views and preferences. One important cultural determinant of economic outcomes is religion (Barro and McCleary 2005; Guiso, Sapienza, and Zingales 2003; Iannaccone and Berman 2008; Renneboog and Spaenjers 2012).

There is a vast literature documenting persistent cultural differences between Protestants and other religious groups. Becker, Pfaff, and Rubin (2016) provide a comprehensive overview. The "Protestant work ethic" hypothesis coined by Weber (1904/1905), according to which Protestants were more hardworking than Catholics and which has long dominated the literature on religious denomination, is still hotly debated with credible results pointing in different directions. Van Hoorn and Maseland (2013) find that Protestants are hurt more by unemployment, and Spenkuch (2017) finds that Protestants work longer hours than Catholics, providing support for Weber's hypothesis. Other studies, however, argue that higher literacy rates (Becker and Woessmann 2009) and institutional development (Arruñada 2010) were more important causes of Protestants being more prosperous than Catholics. Cantoni (2015) finds no effect of the Protestant Reformation on economic growth in Germany. ${ }^{2}$

Arruñada (2010) shows that Protestants' social values are more conducive to economic development than those of Catholics. In an earlier paper, Arruñada (2009) argues that these different social values are due to a different confessional culture. Colvin and McCracken (2016) show that Arruñada's findings persist even during recent times of decreasing church attendance rates. Related research by La Porta et al. (1997) shows that trust is lower in Catholic countries. ${ }^{3}$ Our argument that Protestantism puts more emphasis on adherence to rules and avoidance of moral hazard, which we will lay out in more detail in Section V, builds squarely upon this work by Arruñada.

2. Germany is also in the center of many other studies on the role of religion in economic and social behavior (e.g., Traunmüller 2011; Filistrucchi and Prüfer 2013).

3 . Religious people of all denominations are characterized by higher levels of trust. Gruber (2005) suggests that this effect of religion on trust may be causal. 
While religion has become less important over time in Germany and most other Western countries, religious denomination is, in the vast majority of all cases, exogenously determined by the family into which one is born. We argue that Catholic and Protestant societies are different not because of the contemporary teachings of the churches but rather because previous generations have been exposed to these teachings and passed on their values to their offspring. Conversion at an advanced age is, thus, unlikely to change one's views. In Germany, whether one has grown up in a Catholic or in a Protestant family is highly correlated with the region. The Peace of Augsburg in 1555 is the most important historical event that determined the distribution of Catholics and Protestants in Germany until today. This religious peace treaty gave territorial lords the right to choose their state's official denomination, which then had to be adopted by the entire population living in their domain. Spenkuch and Tillmann (forthcoming) use the resulting religious borders from 1555 to instrument for the regional distribution of Catholics and Protestants in Germany in 1933. They examine the effects of religious denomination on the results of the election that brought the Nazis into power. Becker and Woessmann (2009) and Cantoni (2012) show that distance to Wittenberg, where Luther taught, is a major determinant of the adoption of Protestantism.

\section{EMPIRICAL FRAMEWORK}

\section{A. Data Overview}

We start with an analysis of self-collected data on votes in Germany's national parliament (Bundestag) on a third bailout for Greece from August 19,2015 . We complement this with data on the religious composition of the MPs' constituencies from the 2011 German census, which provides information on the shares of three distinct groups: Protestants, Catholics, and all others combined (including nonreligious people). There are two ways to get elected into the German parliament: either through a simple majority in an electoral district as a direct candidate or through party tickets in the 16 federal states. Many MPs who enter parliament as direct candidates are also listed on party tickets, and many MPs who enter through a party ticket also ran as direct candidates. Due to variations in sizes of population, the electoral districts do not coincide with Germany's administrative districts, for which the 2011 census provides shares of religious denominations. The electoral districts' names are, however, combinations of the names of the administrative districts they are composed of. To merge both datasets, we use those administrative districts, which appear first in the names of the electoral districts. For those MPs who were elected into the parliament on party tickets without representing an electoral district, we use the administrative district, in which their town of residence is located. Various sources, like the official websites of the German Bundestag as well as federal election records, provide individual and constituencyspecific background variables. These include the MPs' age, gender, their own religious denomination, the number of terms in the parliament, whether an MP ran successfully or unsuccessfully as a direct candidate in the electoral district, the number of voters in the constituency, the participation rate in the last election, and results for all parties in the last election for the Bundestag.

The literature on people's economic preferences and beliefs relies strongly on data from social surveys, such as the General Social Survey or the World Values Survey. Our research objectives require us to have information on both religious denomination and people's views on the euro currency, which limits the set of possible alternatives. In our empirical analysis, we inspect people's overall attitudes with evidence from the European Values Survey (EVS). Descriptive statistics for our EVS sample can be found in Appendix Table A1. The main focus of our paper is then on data from Europe's largest household panel SOEP, which allows for an investigation of the link between religious affiliations and attitudes toward the euro in Germany before and during the euro crisis.

The German SOEP is a representative panel survey of the German population (SOEP 2013; Wagner, Frick, and Schupp 2007). In principle, data collection takes place throughout the whole year, with the majority of interviews taking place between late winter and early summer of each year. The SOEP applies a multimode strategy, so that respondents can fill out survey questionnaires on their own or can be interviewed in person by an interviewer.

\section{B. Additional Information on SOEP Data}

As the key prerequisite for our study on the role of religion, the SOEP contains information on people's religious denomination in some of the annual questionnaires. For the years 2003 and 
2011 , which we use in this study, this information is available. ${ }^{4}$ We use data from 2003 because this was the last time before the outbreak of the euro crisis that the SOEP questionnaire contained a question about respondent's view regarding the euro. Previous research on attitudes toward the euro currency focuses on the time of the new currency's introduction (e.g., Luna-Arocas et al. 2001). The topic has received less attention in subsequent years. After the breakout of the euro crisis, however, the SOEP reintegrated the question whether people are concerned about the euro in 2011.

To capture attitudes, each annual SOEP questionnaire contains a large block of questions that begins with: "What is your attitude toward the following areas - are you concerned about them?" Respondents can choose between three possible answers: "Very concerned," "Somewhat concerned," and "Not concerned at all." The list of topics includes various social and economic issues. During the time of the euro implementation, and again in 2011, respondents were asked whether they were concerned about the "introduction of the euro in place of the Deutsche mark." In line with the literature (e.g,, Goebel et al. 2015), we use a dummy indicator for whether respondents say they are "very concerned" to measure euro concerns. Chadi (2015) uses these responses from the 2011 wave to investigate whether strong concerns about the euro matter for people's overall satisfaction with life. Chadi shows that euro skepticism is a causal determinant of lower subjective well-being for a minority of very concerned German citizens and their relative unhappiness helps predict subsequent election results.

To measure subjective well-being, we use the answers to the question "How satisfied are you with your life, all things considered?" The survey respondents have the choice between 11 categories on a scale ranging from 0 (completely dissatisfied) to 10 (completely satisfied). For ease of interpretation, in empirical research on wellbeing, this variable is commonly interpreted linearly (see Ferrer-i Carbonell and Frijters 2004). Personal circumstances may affect both somebody's readiness to express concerns about the

4. The exact question wording is: "Do you belong to a church or religious community? If yes, are you (Catholic, Protestant, etc.)?" The procedure differs from the one in the EVS where people are first asked a simple yes or no question for religion and can then skip a battery of options. In the EVS, the share of respondents who refer to themselves as nondenominational is higher, but still more than half of them report a religious denomination. euro and their subjective well-being. The SOEP data, in particular, allows us to control for a broad range of individual background characteristics. We include, among others, measures of educational attainment, of housing quality, of personal income, and of occupational as well as marital status. Table A2 illustrates the SOEP sample and provides descriptive statistics for Protestants, non-Protestants, and Catholics as a subset of nonProtestants separately.

Being concerned about the euro may also be related to the economic structure of the region in which respondents live. We control for federal states, which may already help us get rid of most of the bias due to differential regional distributions of Protestants and Catholics and of economic conditions within Germany. There may, however, still be variation within federal states. We, therefore, complement the SOEP with measures of regional economic conditions at a finer level of 96 different regions. ${ }^{5}$ We identify two primary channels through which the euro crisis may differentially affect different German regions. On one hand, exposure to risks related to a potential implosion of the euro zone may vary across regions. To capture these risks, we control for regional exports normalized by number of employees and for regional gross domestic product (GDP). On the other hand, the enduring crisis in the struggling euro member countries has induced inflows of labor and capital into Germany. Different regions may have been differentially affected by these inflows. We make use of three stock variables (the share of foreigners in the regional population, the local unemployment rate, and the regional unemployment rate among foreigners only) as proxies for migration and its impact on the local economy. Finally, capital inflows are likely to have differential regional impacts through construction activity. While we do not know if recent construction activity was due to investments from foreigners, we can use information on recently issued construction permits and newly constructed apartments relative to the population, as well as the share of newly constructed apartments among all existing apartments in a region.

5. We have 96 regional identifiers for SOEP respondents. We did not include fixed effects for these regions because there were no Protestants or Catholics in some regions. Instead, we control for regional economic conditions by using INKAR data from the Federal Institute for Research on Building, Urban Affairs and Spatial Development (Bundesinstitut für Bau-, Stadt- und Raumforschung). 
FIGURE 1

Frequency of the Term "Euro Crisis" in Media Reports in 2011

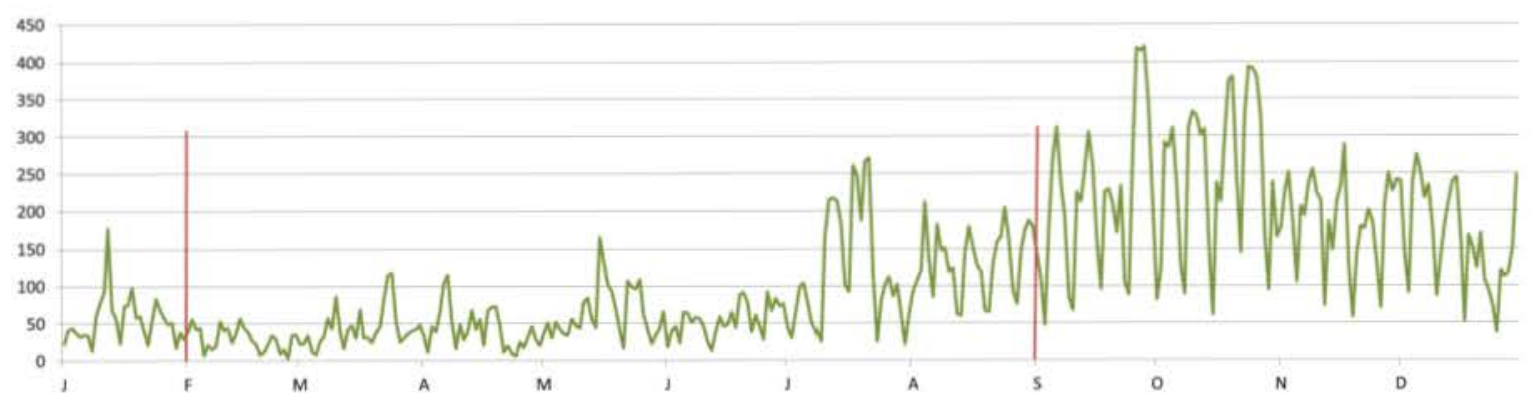

\section{Identification}

While we consider people's religious denomination to be determined exogenously (see Section II), concerns about the euro crisis may be due to a general sentiment of dissatisfaction with life. To address this issue, we exploit the substantial variation in the number of events related to the euro crisis, and thus its media coverage, over the year of 2011. We assume that taking the survey on a specific date is not related to other political or personal circumstances, which makes "media coverage of the euro crisis" a valid instrument as first proposed in Chadi (2015). Table A3 shows the shares of respondents of different denominations in the SOEP across different months in $2011 .^{6}$ The use of this instrument makes our paper part of an emerging literature that exploits interview dates as a source of exogenous variation (Goebel et al. 2015; Metcalfe, Powdthavee, and Dolan 2011; Schüller 2015, 2016).

Daily-level data on media coverage of the euro crisis for the year 2011 comes from LexisNexis. This news aggregator covers many significant media outlets in Germany, most of which

6. To verify that Protestants were not disproportionately surveyed after news events, we regressed our measure of news about the euro crisis on daily and weekly shares of Protestants in the survey. We did not find a statistically significant correlation. With regard to possible differences in media consumption between Catholics and Protestants, we argue that this is less of an issue in the context of the euro crisis, which was hotly debated across the political spectrum and, thus, across media outlets. One might also argue that, while Catholics are more likely to attend church, Protestants may still be more able to read and have more exposure to news (Glaeser and Sacerdote 2008). Indeed, Protestants still have more schooling on average than Catholics $(0.3$ years according to our data in Table A2; 0.8 years according to Becker and Woessmann 2009). Illiteracy is, however, virtually nonexistent in Germany and we control for educational outcomes. have a national audience. Chadi (2015) contains more detailed information on the use of number of media citations of the term "euro crisis" (Eurokrise or Euro-Krise in German) as an instrument. The instrument works best if one takes the aggregate number of media reports mentioning the term "euro crisis" over the day of the interview plus the preceding 3 days. Furthermore, the euro crisis unfolded gradually, and the use of the term "euro crisis" in the media increased throughout the year, as can be seen in Figure 1.

We adjust our instrument for a linear trend for two reasons. First, people probably became acclimated to media coverage on the euro crisis, so that the same event affected people differently at different points in time. Second, the more "euro crisis" became an established term among media people, the more it may have been used and referred to, independently of actual events and economic developments. For our instrumental variable (IV) analysis, we use data from the time between February 1 and August 31, during which the vast majority of SOEP interviews took place. In line with the literature (Chadi 2015; Wunder et al. 2008), we dropped 5 interviews that took place in January and 66 interviews that took place between September and December and use this 7-month period as our period of investigation. The vertical lines in Figure 1 indicate the beginning and the end of our observation period.

Finally, interview mode may affect honesty of respondents when answering questions about both dependent and explanatory variables. Respondents are less likely to report dissatisfaction with life in oral interviews (Conti and Pudney 2011) and less likely to report disapproval of politically sensitive issues like immigration (Janus 2010; Wagner and Schraepler 2001). Chadi (2015) examines the question of survey mode in our context in more detail. 
In the IV analysis, we focus on data from all self-written interview modes (and exclude oral interviews). We show results for the unrestricted sample in the Appendix.

\section{EMPIRICAL RESULTS}

\section{A. Parliamentary Vote on a Third Bailout for Greece}

On August 19, 2015, the German parliament, the Bundestag, voted on whether Germany should support a third bailout for Greece. This third bailout was considered necessary to recapitalize Greek banks and to keep Greece in the euro zone. The proposal was supported by the German government even as tensions with the Greek government and opposition from within Chancellor Angela Merkel's own party, the Christian-conservative CDU and its Bavarian sister party CSU were increasing prior to the vote. While debt relief was explicitly ruled out in the bailout agreements, many Christianconservative MPs were not willing to forgive Greek government officials' behavior, which they had perceived as provocative. Together, the CDU and the CSU form the majority in a grand coalition with the social democrat party, Sozialdemokratische Partei Deutschlands (SPD). Ultimately, 113 of the 631 MPs voted against the bailout, including 63 of $311 \mathrm{CDU} / \mathrm{CSU}$ MPs, which made this the only parliamentary faction within which there was substantial variation in voting behavior. $^{7}$

We analyze all votes in the Bundestag but focus, in particular, on the CDU/CSU for two reasons. First, there were very few dissenters outside the CDU/CSU faction. Second, the CDU and the CSU still highlight Christian values more than other parties in the German parliament. ${ }^{8}$ To be sure, a great deal of the opposition against the bailouts (especially from the left-wing party Die Linke) was due to the sanctions and austerity measures that were part of the bailout agreements. Public statements made by the CDU/CSU dissenters, however, suggest that they were more

7. The SPD and the Green Party supported the bailout, whereas "Die Linke" (The Left) opposed it. The share of dissenters in all of these three parties was at most $2 \%$.

8. The CDU and CSU are the largest conservative parties in Germany. In our context, it is noteworthy that the CDU and CSU are the successors of parties called Zentrum and Bavarian People's Party, which had represented the Catholic minority in Germany until 1933. The parties no longer cater to one particular denomination.
TABLE 1

Descriptive Statistics of CSU Votes on Greece on August 19, 2015

\begin{tabular}{lccccc}
\hline Region & $\begin{array}{c}\text { CSU } \\
\text { MPs }\end{array}$ & Voted No & $\begin{array}{c}\text { Voted } \\
\text { Yes }\end{array}$ & Protestants Catholics \\
\hline Franconia & 18 & $8(44.4 \%)$ & $7(38.9 \%)$ & $35.7 \%$ & $42.9 \%$ \\
Swabia and & 38 & $4(10.5 \%)$ & $29(76.3 \%)$ & $13.5 \%$ & $60.4 \%$ \\
$\quad \begin{array}{l}\text { Old Bavaria } \\
\text { Bavaria }\end{array}$ & 56 & $12(21.4 \%)$ & $36(64.3 \%)$ & $20.7 \%$ & $54.7 \%$ \\
\hline
\end{tabular}

Notes: The numbers in the left-hand panel relate to the vote on a third bailout for Greece, August 19, 2015. Relative numbers do not add up to $100 \%$ because some MPs abstained from the vote. The righthand panel shows shares of Protestants and Catholics in the population in the respective areas according to the 2011 census.

concerned about German taxpayers' money being wasted. ${ }^{9}$

Let us first take a look at the voting behavior of the MPs of the Bavarian CSU. Bavaria is culturally divided into Swabia and Old Bavaria (Schwaben and Altbayern) on one hand, which have vast Catholic majorities, and Franconia (Franken) on the other hand, which has, traditionally, been half Catholic-half Protestant. Table 1 shows that, indeed, CSU MPs from Franconia were more likely to vote against a third bailout for Greece, and less likely to vote in favor of it than CSU MPs form Swabia and Old Bavaria. The table also includes the relative shares of Protestants and Catholics in the Franconian as well as the Swabian and Old Bavarian populations, respectively, according to the 2011 census. Although the simple averages we present may obscure a lot of information, the correlation between voting behavior of the CSU MPs and the religious composition of the populations in the different parts of Bavaria they represent may not, however, be spurious.

Our analysis in Table 2 shows that the correlation persists if we expand our sample to members of parliament outside of the CSU. In a linear probability model, we regress a dummy indicator for voting against the bailout on the shares of people of different religious denominations in the MPs' constituencies and various individual and constituency-specific control variables, as well as federal state dummies. None of these controls produces an effect that is robust to model specification.

Column (1) shows that a 10 percentage point increase in the share of Protestants in an MP's

9. For more details on this vote, which has received substantial attention in national and international media, see, for example, http://www.bbc.com/news/world-europe33975028 . 
TABLE 2

LPM Regression of all Bundestag and CDU/CSU Votes

\begin{tabular}{|c|c|c|c|c|c|c|}
\hline \multirow[b]{3}{*}{ Share Protestants in constituency } & (1) & (2) & (3) & (4) & (5) & (6) \\
\hline & \multicolumn{4}{|c|}{ Bundestag } & \multicolumn{2}{|c|}{ CDU/CSU } \\
\hline & $0.312^{*}$ & $0.426^{* *}$ & 0.263 & $0.379 * *$ & $0.610^{* *}$ & $1.052 * * *$ \\
\hline & $(0.186)$ & $(0.203)$ & $(0.160)$ & $(0.160)$ & $(0.281)$ & $(0.376)$ \\
\hline \multirow[t]{2}{*}{ Share others } & -0.062 & -0.016 & -0.142 & -0.237 & -0.421 & -0.618 \\
\hline & $(0.328)$ & $(0.333)$ & $(0.296)$ & $(0.302)$ & $(0.501)$ & $(0.570)$ \\
\hline \multirow[t]{2}{*}{ Elected directly } & 0.060 & $0.199^{* * *}$ & 0.054 & 0.077 & $0.143^{*}$ & 0.251 \\
\hline & $(0.042)$ & $(0.095)$ & $(0.039)$ & $(0.091)$ & $(0.080)$ & $(0.164)$ \\
\hline \multirow[t]{2}{*}{ Direct $\times$ Protestants } & & -0.260 & & -0.242 & & $-0.601^{1 *}$ \\
\hline & & $(0.190)$ & & $(0.173)$ & & $(0.336)$ \\
\hline \multirow[t]{2}{*}{ Direct $\times$ Others } & & -0.146 & & 0.155 & & 0.244 \\
\hline & & $(0.166)$ & & $(0.154)$ & & $(0.346)$ \\
\hline Parliamentary faction dummies & No & No & Yes & Yes & & \\
\hline Further controls & Yes & Yes & Yes & Yes & Yes & Yes \\
\hline$R^{2}$ & 0.116 & 0.119 & 0.331 & 0.336 & 0.210 & 0.220 \\
\hline Observations & 631 & 631 & 631 & 631 & 311 & 311 \\
\hline
\end{tabular}

Notes: Dependent variable is equal to one for MPs who voted against the third bailout. Estimates are from a linear probability model. Baseline group is Catholics, and Others captures all non-Catholics and non-Protestants in the constituency. The unreported control variables include individual and constituency-specific background measures (age, age squared, gender, own religious denomination, a dummy for whether the current term in the parliament is the first, a dummy for whether the current term is the fourth or higher, a dummy indicating whether an MP ran as a direct candidate in the electoral district but lost, the number of voters in the constituency, the participation rate in the last election, election results for all parties) as well as federal state dummies in all specifications and dummies for parliamentary factions in specifications (3) and (4). Robust standard errors are in parentheses.

$* * * p<.01, * * p<.05, * p<.1$.

constituency at the expense of Catholics (who form the left-out comparison group) would increase the probability of voting against the proposal by 3.1 percentage points, whereas the share of all others taken together does not affect an MP's voting behavior in ways that are significantly different from Catholics. Directly elected MPs appear more likely to dissent, which would be in line with previous research (see Sieberer 2010), but the effect is not statistically significant in all specifications. As shown in columns (2) and (4), we observe no significant interaction between being a directly elected MP and the share of religious denominations in an MP's constituency for the entire Bundestag sample. When we include only CDU/CSU MPs in our analysis, our main coefficient of interest increases substantially in magnitude and becomes statistically significant at the $5 \%$ level. According to column (5), a 10 percentage point increase in the share of Protestants in a CDU/CSU MP's constituency would increase the probability of voting against the proposal by 6.1 percentage points. A weakly significant interaction effect in the last column suggests that this finding is driven by those MPs without a direct mandate. Overall, the analysis confirms that the link between religious denomination in a constituency and voting behavior exists primarily among Christian-conservative MPs.

\section{B. Attitudes toward the Euro among Protestants Before and During the Crisis}

The 2008 EVS allows for a comparison of social values across religious groups in Germany. This survey was conducted at the beginning of the Great Recession and, thus, about 2 years before the European sovereign debt crisis broke out. About half of the respondents said they were not religious. These numbers reflect a well-documented long-term decline in religiosity in Germany, where church attendance rates are lower than, for example, in the United States (Heineck 2001; Iannaccone 1998). The EVS contains a number of items that relate to how respondents think the European Union (EU) may affect them, which allows us to link attitudes toward the EU to religious denomination. We also include a regression on how likely the respondents are to approve of tax fraud, as this is a question that has frequently been discussed in German media in relation to the euro crisis.

Table 3 presents estimates based on this survey. The table includes dummies for whether respondents are Protestants, Muslims, belong to a different religious denomination or none at all; Catholic denomination is the left-out baseline category. In line with Arruñada (2010), the Catholic baseline group is significantly more likely to view tax fraud as morally justifiable 
TABLE 3

Ordered Probit Estimates

\begin{tabular}{|c|c|c|c|c|c|}
\hline & \multirow[b]{2}{*}{$\begin{array}{c}\text { (1) } \\
\text { Justify } \\
\text { Tax Fraud }\end{array}$} & \multicolumn{4}{|c|}{ EU-Related Fears } \\
\hline & & $\begin{array}{c}(2) \\
\text { Loss Social } \\
\text { Security }\end{array}$ & $\begin{array}{c}\text { (3) } \\
\text { Loss } \\
\text { National Culture }\end{array}$ & $\begin{array}{c}\text { (4) } \\
\text { Own } \\
\text { Country Pays }\end{array}$ & $\begin{array}{l}\text { (5) } \\
\text { Loss of } \\
\text { Jobs }\end{array}$ \\
\hline Protestant & $\begin{array}{c}-0.233^{* * * * *} \\
(0.071)\end{array}$ & $\begin{array}{l}-0.013 \\
(0.063)\end{array}$ & $\begin{array}{c}-0.134^{* * *} \\
(0.064)\end{array}$ & $\begin{array}{l}-0.071 \\
(0.064)\end{array}$ & $\begin{array}{c}0.033 \\
(0.065)\end{array}$ \\
\hline Muslim & $\begin{array}{l}-0.182 \\
(0.223)\end{array}$ & $\begin{array}{c}0.040 \\
(0.189)\end{array}$ & $\begin{array}{r}-0.080 \\
(0.151)\end{array}$ & $\begin{array}{l}-0.100 \\
(0.195)\end{array}$ & $\begin{array}{l}-0.024 \\
(0.227)\end{array}$ \\
\hline Other religion & $\begin{array}{c}-0.440^{* * *} \\
(0.180)\end{array}$ & $\begin{array}{l}-0.179 \\
(0.175)\end{array}$ & $\begin{array}{c}-0.337^{* *} * \\
(0.168)\end{array}$ & $\begin{array}{l}-0.184 \\
(0.158)\end{array}$ & $\begin{array}{l}-0.080 \\
(0.159)\end{array}$ \\
\hline No religion & $\begin{array}{c}-0.346^{* * * *} \\
(0.064)\end{array}$ & $\begin{array}{c}0.161^{* * *} \\
(0.060)\end{array}$ & $\begin{array}{c}-0.329 * * * \\
(0.061)\end{array}$ & $\begin{array}{l}-0.004 \\
(0.060)\end{array}$ & $\begin{array}{l}0.107 * \\
(0.060)\end{array}$ \\
\hline University & $\begin{array}{l}-0.102 \\
(0.111)\end{array}$ & $\begin{array}{c}-0.369 * * * \\
(0.102)\end{array}$ & $\begin{array}{c}-0.350^{* * * *} \\
(0.095)\end{array}$ & $\begin{array}{c}-0.298^{* * * *} \\
(0.093)\end{array}$ & $\begin{array}{c}-0.220^{* * *} \\
(0.100)\end{array}$ \\
\hline Apprenticeship & $\begin{array}{l}-0.070 \\
(0.088)\end{array}$ & $\begin{array}{c}0.119 \\
(0.078)\end{array}$ & $\begin{array}{l}-0.024 \\
(0.075)\end{array}$ & $\begin{array}{c}0.176^{* * *} \\
(0.078)\end{array}$ & 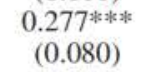 \\
\hline Other educational degree & $\begin{array}{l}-0.008 \\
(0.103)\end{array}$ & $\begin{array}{l}-0.048 \\
(0.089)\end{array}$ & $\begin{array}{c}-0.160 * \\
(0.086)\end{array}$ & $\begin{array}{l}-0.042 \\
(0.091)\end{array}$ & $\begin{array}{c}0.015 \\
(0.091)\end{array}$ \\
\hline Age/10 & $\begin{array}{c}-0.125^{* * * *} \\
(0.016)\end{array}$ & $\begin{array}{c}0.016 \\
(0.015)\end{array}$ & $\begin{array}{c}0.017 \\
(0.014)\end{array}$ & $\begin{array}{c}0.030^{\text {*** }} \\
(0.015)\end{array}$ & $\begin{array}{c}-0.057 \text { **** } \\
(0.016)\end{array}$ \\
\hline Female & $\begin{array}{l}-0.205 \\
(0.053)\end{array}$ & $\begin{array}{c}0.103 * * \\
(0.047)\end{array}$ & $\begin{array}{l}-0.042 \\
(0.046)\end{array}$ & $\begin{array}{l}-0.015 \\
(0.047)\end{array}$ & $\begin{array}{c}0.057 \\
(0.048)\end{array}$ \\
\hline Pseudo- $R^{2}$ & 0.019 & 0.008 & 0.007 & 0.006 & 0.011 \\
\hline Observations & 2036 & 2002 & 2015 & 1991 & 2017 \\
\hline
\end{tabular}

Note: Robust standard errors are in parentheses.

**** $p<.01,{ }^{*} * p<.05,{ }^{*} p<.1$.

than the other groups. As can be seen in column (4), German Protestants were not more likely than other religious groups to think that their own country had to pay for other EU members. Answers to the other questions also suggest that in 2008, Protestants were not more or less critical of the EU than members of other religious groups. In 2008, Protestants differed from Catholics only in their views toward tax fraud and in how they thought the EU would affect their national culture. At a first glance, Table 3 appears not to lend much support to the central hypothesis of our paper.

Table 4, however, which compares attitudes toward the euro of the exact same individuals in 2003 and 2011, shows that the opinion of Protestants has changed significantly as the euro crisis unfolded. In 2003, when Germany still had trouble meeting the Maastricht criteria itself, Protestants were actually less likely to report concerns about the common European currency. In 2011, this was different, as shown by the coefficients on the interaction terms between Protestant denomination and year 2011. Although this interaction term is only statistically significant in specifications (1) and (3) without additional interaction terms for other religious affiliations, the coefficients always cancel out with those on Protestant denomination.

Columns (5) to (10) repeat the same analysis with separate samples for 2003 and 2011. As before, in the restricted sample with only individuals who were surveyed in both years, Protestants were less skeptical of the common currency in 2003, but not in 2011, compare columns (5) and (8). We also show specifications that include individuals that were not in the sample in both years. In the full samples in columns (6) and (9), and in samples that include only respondents with religious denomination in columns (7) and (10), the picture becomes even stronger: the Protestant dummy becomes statistically significant, again, but with the opposite, positive sign compared to 2003. In 2011, Protestants are, conditional on covariates including personal background and regional economic conditions, even more critical of the euro than Catholics. This change in a typically rather stable economic belief raises the question if different views on the euro among Protestants and Catholics differentially affected subjective well-being, as well.

Table 5 shows results of regressions of subjective well-being on concerns about the euro, on religious denomination, and on interaction terms 
TABLE 4

Religious Denomination and Changes in Euro Concerns

\begin{tabular}{|c|c|c|c|c|c|c|c|c|c|c|}
\hline & \multicolumn{4}{|c|}{2003 and 2011} & \multicolumn{3}{|c|}{${ }_{2003}^{(6)}$} & \multicolumn{3}{|c|}{ (9) 2011} \\
\hline & \multicolumn{4}{|c|}{ Balanced Sample over Both Years } & $\begin{array}{c}\text { Balanced } \\
\text { with } \\
2011\end{array}$ & $\begin{array}{c}\text { Full } \\
\text { Sample } \\
\text { for } 2003\end{array}$ & $\begin{array}{c}\text { Only } \\
\text { Individuals } \\
\text { with } \\
\text { Denomination }\end{array}$ & $\begin{array}{c}\text { Balanced } \\
\text { with } \\
2003\end{array}$ & $\begin{array}{l}\text { Full Sample } \\
\text { for } 2011\end{array}$ & $\begin{array}{l}\text { Only Individuals } \\
\text { with Denomination }\end{array}$ \\
\hline Protestant & 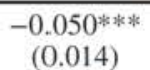 & 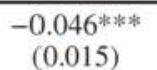 & $\begin{array}{c}-0.030^{\text {*** }} \\
(0.013)\end{array}$ & $\begin{array}{c}-0.028^{*} \\
(0.015)\end{array}$ & $\begin{array}{c}-0.032^{* * *} \\
(0.015)\end{array}$ & $\begin{array}{c}-0.034 * * \\
(0.013)\end{array}$ & $\begin{array}{c}-0.032^{\text {**** }} \\
(0.013)\end{array}$ & $\begin{array}{c}0.004 \\
(0.016)\end{array}$ & $\begin{array}{l}0.023^{*} \\
(0.014)\end{array}$ & $\begin{array}{l}0.032 * * \\
(0.014)\end{array}$ \\
\hline Other religion & $\begin{array}{c}0.025 \\
(0.023)\end{array}$ & $\begin{array}{c}0.053 \\
(0.032)\end{array}$ & $\begin{array}{l}-0.001 \\
(0.025)\end{array}$ & $\begin{array}{c}0.034 \\
(0.034)\end{array}$ & $\begin{array}{c}0.002 \\
(0.035)\end{array}$ & $\begin{array}{l}-0.019 \\
(0.032)\end{array}$ & $\begin{array}{l}-0.027 \\
(0.032)\end{array}$ & $\begin{array}{c}0.001 \\
(0.033)\end{array}$ & $\begin{array}{c}0.028 \\
(0.030)\end{array}$ & $\begin{array}{c}0.030 \\
(0.031)\end{array}$ \\
\hline No denomination & $\begin{array}{l}-0.000 \\
(0.012) \\
-0.011 \\
(0.011)\end{array}$ & $\begin{array}{l}0.003 \\
(0.016) \\
-0.005 \\
(0.017)\end{array}$ & $\begin{array}{l}-0.012 \\
(0.013) \\
-0.025 \\
(0.023)\end{array}$ & $\begin{array}{l}-0.012 \\
(0.017) \\
-0.018 \\
(0.026)\end{array}$ & $\begin{array}{l}-0.025 \\
(0.018)\end{array}$ & $\begin{array}{c}-0.038^{* *} \\
(0.015)\end{array}$ & & $\begin{array}{l}-0.006 \\
(0.018)\end{array}$ & $\begin{array}{c}0.023 \\
(0.015)\end{array}$ & \\
\hline Protestant $\times 2011$ & $\begin{array}{l}0.040^{* *} * \\
(0.018)\end{array}$ & $\begin{array}{c}0.033 \\
(0.017)\end{array}$ & $\begin{array}{l}0.033^{*} \\
(0.017)\end{array}$ & $\begin{array}{c}0.028 \\
(0.021)\end{array}$ & & & & & & \\
\hline Other $\times 2011$ & & $\begin{array}{l}-0.049 \\
(0.045)\end{array}$ & & $\begin{array}{l}-0.064 \\
(0.042)\end{array}$ & & & & & & \\
\hline No denomination $\times 2011$ & & $\begin{array}{l}-0.006 \\
(0.023)\end{array}$ & & $\begin{array}{l}-0.001 \\
(0.024)\end{array}$ & & & & & & \\
\hline Controls & No & No & Yes & Yes & Yes & Yes & Yes & Yes & Yes & Yes \\
\hline Observations & 18,364 & 18,364 & 18,364 & 18,364 & 9,182 & 12,061 & 8,119 & 9,182 & 12,518 & 8,227 \\
\hline$R^{2}$ & 0.002 & 0.002 & 0.077 & 0.078 & 0.088 & 0.082 & 0.100 & 0.096 & 0.096 & 0.109 \\
\hline
\end{tabular}

Notes: Estimates are from a linear probability model. Dependent variable is being very concerned about the euro. Reference category for religious affiliation is Catholic. Set of controls includes variables for gender, migration background (number of variables is 2), age (3), nationality (4), education (4), employment (6), retirement, income, house ownership, housing conditions (4), household composition (3), family status (4), partnership, health status (3), recent life events (6), federal state (15), years in the panel (26), and interview mode (5), as well as regional variables (8). Also included are the Big Five personality factors with a set of 10 binary variables for high and low extraversion, agreeableness, conscientiousness, neuroticism, an openness. Robust standard errors are in parentheses. Survey weights are used. SOEP data from 2003 respectively 2011 (with Big Five measures from 2009) are used.

$$
* * * p<.01, * * p<.05, * p<.1 \text {. }
$$


TABLE 5

Subjective Well-being as Dependent Variable and Concerns about the Euro

\begin{tabular}{|c|c|c|c|c|c|c|c|c|}
\hline \multirow{2}{*}{$\begin{array}{l}\text { Year: } \\
\text { Sample Restriction: }\end{array}$} & $\begin{array}{c}(1) \\
2003\end{array}$ & $\begin{array}{c}(2) \\
2003\end{array}$ & $\begin{array}{c}(3) \\
2003\end{array}$ & $\begin{array}{c}(4) \\
2011\end{array}$ & $\begin{array}{c}(5) \\
2011\end{array}$ & $\begin{array}{c}(6) \\
2011\end{array}$ & $\begin{array}{c}(7) \\
2011\end{array}$ & $\begin{array}{c}(8) \\
2011\end{array}$ \\
\hline & \multicolumn{3}{|c|}{ Balanced with 2011} & \multicolumn{3}{|c|}{ Balanced with 2003} & \multicolumn{2}{|c|}{ Main Sample } \\
\hline \multirow[t]{2}{*}{ Protestant } & 0.033 & 0.052 & 0.049 & -0.012 & 0.065 & 0.061 & -0.057 & -0.055 \\
\hline & $(0.059)$ & $(0.062)$ & $(0.063)$ & $(0.065)$ & $(0.067)$ & $(0.069)$ & $(0.056)$ & $(0.058)$ \\
\hline \multirow[t]{2}{*}{ Other religion } & -0.195 & -0.195 & -0.227 & -0.218 & -0.214 & -0.265 & -0.202 & $-0.254 *$ \\
\hline & $(0.166)$ & $(0.166)$ & $(0.185)$ & $(0.160)$ & $(0.160)$ & $(0.170)$ & $(0.136)$ & $(0.146)$ \\
\hline No denomination & $\begin{array}{c}-0.133^{*} \\
(0.071)\end{array}$ & $\begin{array}{c}-0.134 * \\
(0.071)\end{array}$ & $\begin{array}{c}-0.135^{*} \\
(0.073)\end{array}$ & $\begin{array}{l}-0.068 \\
(0.075)\end{array}$ & $\begin{array}{l}-0.067 \\
(0.075)\end{array}$ & $\begin{array}{l}-0.062 \\
(0.078)\end{array}$ & $\begin{array}{c}-0.121^{*} \\
(0.065)\end{array}$ & $\begin{array}{l}-0.105 \\
(0.069)\end{array}$ \\
\hline Concerned about & $-0.427 * * *$ & -0.396 **** & $-0.410^{* * * *}$ & $-0.374 * * *$ & $-0.261 * * *$ & $-0.272^{* *}$ & $-0.210^{* * *}$ & $-0.193^{*}$ \\
\hline the euro & $(0.060)$ & $(0.072)$ & $(0.113)$ & $(0.066)$ & $(0.078)$ & $(0.122)$ & $(0.066)$ & $(0.101)$ \\
\hline Protestant $\times$ & & -0.097 & -0.083 & & $-0.362 * * *$ & $-0.351^{* *}$ & $-0.283^{* * *}$ & $-0.301^{* *} *$ \\
\hline Euro concerns & & $(0.129)$ & $(0.156)$ & & $(0.136)$ & $(0.167)$ & $(0.119)$ & $(0.142)$ \\
\hline Other religion $x$ & & & 0.144 & & & 0.274 & & 0.268 \\
\hline Euro concerns & & & $(0.279)$ & & & $(0.297)$ & & $(0.249)$ \\
\hline No conf. $x$ & & & 0.007 & & & -0.025 & & -0.081 \\
\hline Euro concerns & & & $(0.154)$ & & & $(0.162)$ & & $(0.137)$ \\
\hline Observations & 9,182 & 9,182 & 9,182 & 9,182 & 9,182 & 9,182 & 12,518 & 12,518 \\
\hline$R^{2}$ & 0.232 & 0.232 & 0.232 & 0.241 & 0.243 & 0.243 & 0.226 & 0.226 \\
\hline
\end{tabular}

Notes: Dependent variable is well-being on a 0 to 10 scale. Reference category for religious affiliation is Catholic. See Table 4 for the controls. Robust standard errors are in parentheses. Survey weights are used. SOEP data from 2003 respectively from 2011 (with Big Five measures from 2009) are used.

*** $p<.01,{ }^{* *} p<.05,{ }^{*} p<.1$.

between these variables. ${ }^{10}$ Across all years and all samples, concerns about the euro are negatively correlated with subjective well-being. This is true for members of all different religious groups. In 2011, however, this negative correlation suddenly becomes much stronger among Protestants than among members of all other religious groups. This is true both if we look at a balanced sample of individuals who responded to both surveys in 2003 and 2011, and if we include all 2011 respondents in the sample.

The estimates in Table 5 do not necessarily reflect causal relationships. It could be that Protestants have become less happy between 2003 and 2011, and that the increased concerns about the euro are a mere reflection of their reduced subjective well-being. Using the media coverage instrument outlined in Section III.C, however, we show next that Protestants are actually more sensitive to news about the euro crisis. We demonstrate that concerns about the euro causally reduce the subjective well-being of Protestants, but not that of members of other religious denominations. ${ }^{11}$

10. In contrast to Table 4 , here we only work with separate samples for 2003 and 2011 to avoid specifications that include not only interaction terms between year and Protestant denomination as well as year and euro concerns, but also triple interaction terms between year 2011 and all interaction terms.

11. The set of controls used in the regressions in this section includes measures of the Big Five personality traits,

\section{The Effect of Euro Concerns on Subjective Well-Being}

The upper panel of Table 6 shows reduced form estimates for our model. We regress subjective well-being on the measure of media reports about the euro crisis during the days before the interview, which we outlined in Section III.C. We observe a significant negative effect of our exogenous instrument on subjective well-being among Protestants, but not among non-Protestants nor among Catholics as a subset of the non-Protestants. The effect among Protestants is strong enough to produce a significant relationship between the exogenous instrument and subjective well-being in the full sample. We have now established a link between the exogenous event media reports on the euro crisis and subjective well-being among Protestants. We next address the question whether those respondents whose subjective well-being was reduced by the news were actually concerned about the fate of the joint currency.

The lower panel of Table 6 shows estimation results for the first-stage regressions of the IV procedure. We observe that media reports on the euro crisis led to increased concerns about the

which are often used in this literature to address identification issues. In the following Section IV.C we will not include the Big Five personality traits. Our results, however, are robust to their inclusion. 
TABLE 6

Reduced Form and First Stage Estimation Results

\begin{tabular}{lcccc}
\hline & $\begin{array}{c}(\mathbf{1}) \\
\text { Protestants }\end{array}$ & $\begin{array}{c}(\mathbf{2}) \\
\text { Non-Protestants }\end{array}$ & $\begin{array}{c}(\mathbf{3}) \\
\text { Catholics }\end{array}$ & $\begin{array}{c}\mathbf{( 4 )} \\
\text { Full Sample }\end{array}$ \\
\hline \multirow{2}{*}{ News } & \multicolumn{1}{c}{ Reduced form estimates: subjective well-being and news } & -0.194 & $-0.309^{* * *}$ \\
& $-0.551^{* * *}$ & -0.124 & $(0.197)$ & $(0.133)$ \\
Controls & $(0.233)$ & $(0.156)$ & Yes & 6,436 \\
Observations & Yes & Yes & 1,705 & 0.199 \\
$R^{2}$ & 2,071 & 4,365 & 0.260 & $0.155^{* * * *}$ \\
& 0.233 & 0.220 & $0.161^{* * *}$ & $(0.037)$ \\
News & First stage: concerns about the euro and news & $(0.067)$ & yes \\
& $0.195^{* * *}$ & $0.128^{* * *}$ & 1,705 & 6,436 \\
Controls & $(0.056)$ & $(0.045)$ & 0.194 & 0.125 \\
Observations & yes & 4,365 & 5.725 & 17.496 \\
$R^{2}$ & 2,071 & 0.122 & \\
$F$-test on instrument & 0.222 & 8.207 & & \\
\hline
\end{tabular}

Notes: Dependent variable in upper panel is well-being on a 0 to 10 scale. Dependent variable in lower panel is being very concerned about the euro. Construction of the "news" variable is explained in Section III.C. Control variables are the same as in Table 4, except for Big Five personality measures, which are not included. Robust standard errors are in parentheses.

**** $p<.01, * * p<.05, * p<.1$.

TABLE 7

Second Stage: Subjective Well-Being Explained by Instrumented Concerns about the Euro

\begin{tabular}{|c|c|c|c|c|c|c|c|c|}
\hline & (1) & (2) & (3) & (4) & (5) & (6) & (7) & (8) \\
\hline & \multicolumn{2}{|c|}{ Protestants } & \multicolumn{2}{|c|}{ Non-Protestants } & \multicolumn{2}{|c|}{ Catholics } & \multicolumn{2}{|c|}{ All Denominations } \\
\hline & IV & OLS & IV & OLS & IV & OLS & IV & OLS \\
\hline \multirow[b]{2}{*}{ Euro concerns } & \multicolumn{2}{|c|}{ No interviewer present } & & & & & & \\
\hline & $-2.827 * *$ & $-0.726^{* * * * *}$ & -0.970 & $-0.343 * * *$ & -1.205 & $-0.452 * * *$ & $\begin{array}{c}-1.997 * * \\
(0.892)\end{array}$ & $\begin{array}{c}-0.463 * * * \\
(0.084)\end{array}$ \\
\hline Controls & Yes & Yes & Yes & Yes & Yes & Yes & Yes & Yes \\
\hline Observations & 2,071 & 2,071 & 4,365 & 4,365 & 1,705 & 1,705 & 6,436 & 6,436 \\
\hline$R^{2}$ & 0.070 & 0.251 & 0.207 & 0.223 & 0.243 & 0.269 & 0.099 & 0.204 \\
\hline
\end{tabular}

Notes: Dependent variable is well-being on a 0 to 10 scale. Control variables are the same as in Table 4, except for Big Five personality measures, which are not included. Robust standard errors are in parentheses.

**** $p<.01, * * p<.05, * p<.1$.

euro in all subgroups. The $F$-statistics in columns (1) and (4) are greater than 10 and, thus, in line with the rule of thumb for one endogenous regressor (Staiger and Stock 1997). ${ }^{12}$ Despite significantly positive coefficients, the instrument is weak for non-Protestants and for Catholics on their own.

Table 7 shows results for the second stage of our IV procedure in the odd-numbered columns along with corresponding ordinary least squares (OLS) estimates of the effect of euro concerns on subjective well-being. While, according to levels of significance, Protestants did not stand

12. Given the number of control variables, there may, however, still be size distortions (Stock and Yogo 2005). We, therefore, compare the estimates of the second stage with results of OLS regressions. For the regression output for the full model with regression coefficients for all control variables in column (4), see Appendix Table A4. out as being different in the first stage, they are the only group for which we can observe a causal effect of euro concerns on subjective wellbeing. While the IV estimates among the nonProtestants and Catholics are negative and larger in magnitude than the OLS estimates, they are not statistically significant. In the combined sample of all denominations, we observe an effect that is negative and statistically significant. However, this effect appears to be entirely driven by the Protestants in our sample.

Chadi (2015) emphasizes the importance of different survey modes. This justifies the exclusion of all observations for which an interviewer was present all the time. The remaining sample consists primarily of surveys that were submitted by mail or that were later picked up by interviewers who were not present while respondents answered the surveys. Results in 
Table A5 show that the relationship between subjective well-being and euro concerns on one hand, and frequency of the term "euro crisis" in the news, indeed, becomes weaker but does not disappear if we include personal interviews. Results in Table A6 show that the causal effect of news on the euro crisis becomes smaller if we include interviews with interviewer presence but remains statistically significant at the $10 \%$ level.

If we look at the simple OLS estimates in columns (2), (4), (6), and (8), we observe a negative relationship between euro concerns and the subjective well-being among all different subgroups. Our IV results, however, suggest causal effects among Protestants only. In all subgroups, the IV coefficients are more negative than the OLS coefficients, reflecting the LATE property of IV estimation. Imbens and Angrist (1994) showed that IV estimation measures causal effects only for "compliers," that is, for individuals for whom the instrumental variable affects the endogenous variable in the way desired by the researcher. Our compliers are those individuals who become more worried after reading news about the euro crisis. In this subset, the coefficient captures not only the negative correlation between euro concerns and subjective well-being, but also the negative news effects. The magnitude of the coefficient for Protestants in column (1) of -2.8 corresponds to one-quarter of the entire scale ranging from 0 to 10 , and to $40 \%$ of the average well-being among Protestants of $6.89 . .^{13}$

Why does news about the euro crisis reduce the subjective well-being of German Protestants, whereas others, including Catholics, appear to be more resilient toward such adverse macro shocks? In the next section, we discuss how history provides a possible explanation for our findings.

\section{DISCUSSION: PROTESTANTISM AND MORAL HAZARD}

While we cannot rule out other explanations, our discussion focuses on one possible, albeit somewhat speculative, interpretation,

13. We make use of other questions on people's concerns available in the SOEP. Placebo variables such as concerns about the environment, concerns about general economic development, and concerns about one's own economic situation do not respond to our news instrument. News about the euro crisis has, thus, not increased economic uncertainty overall. which relates our findings to different attitudes toward moral hazard. ${ }^{14}$ Confession is one of seven Catholic sacraments, whereby a believer confesses his sins to a priest, expresses regret, and is absolved. It is obvious to an economist that confession allows for intertemporal substitution. ${ }^{15}$ Protestants, on the other hand, believe they will be accountable for everything they did during their lives. In fact, the roots for Protestantism were laid when Martin Luther protested against a sixteenth-century practice of selling indulgences. ${ }^{16}$ Thus, we argue that moral hazard considerations are more important to Protestants than to others, including Catholics.

This view corroborates the notion that Protestants care more about rules. In the modern German language, which has been shaped by Luther's translation of the Bible, the word for debt-Schuld-is the same as for guilt or blame. In line with the view that Protestantism considers it a moral obligation to make up for debt, Stulz and Williamson (2003) find that predominantly Protestant countries offer more legal protection for creditors. Catholics, on the other hand, still appear more likely to consider creditors the immoral party in debt transactions, believing that one can get rid of debt, like guilt, through forgiveness. ${ }^{17}$ Stulz and Williamson (2003) trace this back to a Catholic tradition, under which usury led to excommunication. They argue that, in particular, the Calvinist

14. According to a different explanation, Catholic theology tends to be more collective, while that of Protestants is more individualistic. Franck (2010) and Strulik (2016) illustrate this using Pope Leo XII's encyclical "Rerum Novarum" of 1891 , in which the Catholic Church sided with the labor movement and criticized unrestricted capitalism in response to social conflict during the late nineteenth century. Becker and Woessmann (2015) argue in a similar direction by interpreting their finding that Protestantism had a significant effect on suicide as evidence that Protestantism is less socially cohesive than Catholicism. Note that this explanation is closely related to ours: If the Protestant social ethic emphasizes individualistic values, this implies that individuals will have to take responsibility for their actions, in turn engendering stronger avoidance of moral hazard.

15. For a thorough economic analysis of the sacrament of confession, see Arruñada (2009). In this paper and in Arruñada (2010), he points out that cultural differences between Protestants and Catholics are due to different dealings with sin and guilt. Note that the German word for denomination is Konfession.

16. Indulgences are "remissions before God of the temporal punishment due to sins whose guilt has already been forgiven" according to the Catechism of the Catholic Church: http://www.vatican.va/archive/ENG0015/_P4G.HTM.

17. Catholics maintain a version of the Jewish tradition of "Jubilee," whereby every 50 years debts are forgiven and special absolution is given. 
Reformation has played an essential role in the development toward making interest a normal part of commerce. They find that interest is still more widely accepted among Protestants than among Catholics.

Protestant ethics is based on uniform moral standards that apply to all individuals and across time. Martin Luther was not willing to give up his principles even under the threat of criminal prosecution. Confronting Catholic Emperor Charles V during the Diet of Worms in 1521, Luther refused to recant his writings, allegedly saying: "Here I stand. I cannot do otherwise." Catholic priests, on the other hand, have traditionally been trained to fine-tune moral standards following prescriptions devised by medieval theologists for different circumstances (Arruñada 2009, 2010). Similarly, during the sovereign debt crisis, European leaders have repeatedly had to decide whether to apply homogeneous standards across countries. Bowlby (2012), among others, compares Angela Merkel's assertion that there is no alternative to austerity to the Luther quote cited above. Crucially, if these standards apply for all countries, they must not be changed across time either. Expectations that running unsustainable fiscal deficits will not be sanctioned may foster moral hazard. ${ }^{18}$

\section{CONCLUSION}

The euro crisis has produced a "religious fault line" (Bowlby 2012) between Catholic countries on one hand, and Protestant countries on the other hand. Cultural differences between different religious denominations are a possible explanation for the euro crisis, and may also have shaped how policymakers responded to it. Germany traditionally has both Protestant and Catholic populations, which raises the question if Catholics and Protestants differ in how they responded to the euro crisis within Germany, too. We show that these attitudes, indeed, differ between Protestants and non-Protestants, thus offering a novel explanation for the great variation in policymakers' and the general population's responses to the euro crisis.

18. There is supportive evidence showing that Catholics have been more supportive of European integration than Protestants, and that this may be related to "confessional culture" (Vollaard 2006; Nelsen and Guth 2003). Guiso, Herrera, and Morelli (2016) quote from a conversation with Thomas Wieser, Chairman of the Economic and Financial Committee of the European Union, according to whom policymakers' different approaches toward the euro crisis can be explained by the religious denomination that is dominant in the country which they represent.
In this paper, we first demonstrate that religious denomination matters for voting behavior in the context of the euro crisis. A higher share of Protestants in their constituencies tended to increase the probability of a (Christianconservative) MP to vote against the bailout. We then show that German Protestants continue to have different social values than German Catholics: Catholics are still more likely to consider tax fraud, which was frequently discussed in the media in relation to the euro crisis, as morally justifiable. According to survey data from the German SOEP, Protestants were less concerned about the fate of the joint currency than non-Protestants in 2003, when Germany was still not able to meet the Maastricht Treaty's fiscal deficit criteria itself. By 2011, however, when the crisis was most severe, Protestants had become more concerned than non-Protestants. We, furthermore, observe a negative association between euro concerns and subjective well-being in the whole population. In 2011, however, this negative association was stronger among Protestants than among non-Protestants.

To obtain causal estimates of the effect of euro concerns on subjective well-being, we exploit exogenous variation in the timing of the interviews conducted for the SOEP in 2011. In the first-stage regressions, we find a positive correlation between news about the euro crisis during the days prior to the interviews and euro concerns across all religious denominations. Only among Protestants, however, is this correlation strong enough to justify the use of our instrument. In the second stage, we find a negative causal effect of euro concerns on subjective well-being among Protestants, but not among non-Protestants. This effect among Protestants is statistically significant and of substantial magnitude.

Our findings are in line with Protestants being more sensitive toward moral hazard considerations. Religious confession continues to shape our views on subjects like the euro, which, at first glance, have little relation to religion. While our work does not offer a new approach on how to address fiscal imbalances, it does, however, help to understand sensitivities during the euro crisis and suggests that such sensitivities may matter in other contexts as well. As attitudes toward monetary policy may differ across countries, future research may extend our analysis beyond Germany's borders. We believe, however, that Germany is a suitable option for an investigation of the religious faultline between Protestants and Catholics. 
APPENDIX

TABLE A1

EVS: Descriptive Statistics

\begin{tabular}{|c|c|c|c|c|c|c|c|}
\hline Variables & Obs & Mean & Standard Deviation & Min & $\operatorname{Max}$ & $\mathbf{m} \mid$ Prot & m|Cath \\
\hline Catholic & 2,075 & 0.227 & 0.419 & 0 & 1 & 0 & 1 \\
\hline Other religion & 2,075 & 0.024 & 0.152 & 0 & 1 & 0 & 0 \\
\hline No religion & 2,075 & 0.466 & 0.499 & 0 & 1 & 0 & 0 \\
\hline EU: fear loss of social security & 2,026 & 7.164 & 2.719 & 1 & 10 & 7.078 & 7.047 \\
\hline EU: fear of job losses & 2,040 & 7.854 & 2.452 & 1 & 10 & 7.868 & 7.775 \\
\hline Justify tax fraud & 2,060 & 1.966 & 1.628 & 1 & 10 & 1.930 & 2.209 \\
\hline University & 2,075 & 0.120 & 0.326 & 0 & 1 & 0.105 & 0.096 \\
\hline Apprenticeship, vocational education & 2,075 & 0.573 & 0.495 & 0 & 1 & 0.601 & 0.601 \\
\hline Other educational degree & 2,075 & 0.189 & 0.392 & 0 & 1 & 0.173 & 0.187 \\
\hline Compulsory or no education & 2,075 & 0.111 & 0.314 & 0 & 1 & 0.116 & 0.113 \\
\hline
\end{tabular}

TABLE A2

SOEP: Detailed Descriptive Statistics

\begin{tabular}{|c|c|c|c|}
\hline 2003 & Protestants & Non-Protestant & Catholic \\
\hline Subjective well-being & 7.1030 & 6.8575 & 7.0951 \\
\hline Concerned about the euro & 0.1874 & 0.2350 & 0.2314 \\
\hline Observations & 4,117 & 7,944 & 3,387 \\
\hline 2011 & Protestants & Non-Protestant & Catholic \\
\hline Subjective well-being & 6.8920 & 6.8204 & 6.9636 \\
\hline Concerned about the euro & 0.2043 & 0.2130 & 0.2040 \\
\hline Female & 0.5568 & 0.4931 & 0.5163 \\
\hline No migration background & 0.9073 & 0.7948 & 0.7816 \\
\hline Direct migration background & 0.0570 & 0.1373 & 0.1341 \\
\hline Indirect migration background & 0.0356 & 0.0679 & 0.0843 \\
\hline Age & 54.2969 & 51.0693 & 52.1545 \\
\hline Nationality: German & 0.9831 & 0.8896 & 0.9014 \\
\hline Nationality: Turkish & 0.0000 & 0.0298 & 0.0000 \\
\hline Nationality: Italian & 0.0017 & 0.0200 & 0.0429 \\
\hline Nationality: Greek & 0.0002 & 0.0043 & 0.0001 \\
\hline Nationality: others & 0.0150 & 0.0563 & 0.0556 \\
\hline Education: primary & 0.1449 & 0.1505 & 0.1769 \\
\hline Education: secondary & 0.6560 & 0.6437 & 0.6449 \\
\hline Education: tertiary & 0.1991 & 0.2059 & 0.1781 \\
\hline Education years & 12.2390 & 12.1509 & 11.9573 \\
\hline Employment: full-time & 0.3449 & 0.4340 & 0.4095 \\
\hline Employment: regular part-time & 0.1150 & 0.1069 & 0.1243 \\
\hline Employment: marginal, irregular part-time & 0.0525 & 0.0539 & 0.0545 \\
\hline Employment: other forms (e.g., retraining) & 0.0188 & 0.0139 & 0.0144 \\
\hline Employment: out of labor force & 0.4688 & 0.3914 & 0.3973 \\
\hline Registered as unemployed & 0.0364 & 0.0620 & 0.0311 \\
\hline Retired & 0.0597 & 0.0581 & 0.0458 \\
\hline Self-employed & 0.3588 & 0.2642 & 0.2902 \\
\hline Equalized real income & 1738.9030 & 1749.1240 & 1786.2507 \\
\hline Owner of dwelling & 0.5560 & 0.4649 & 0.5637 \\
\hline Dwelling: in good condition & 0.6897 & 0.6938 & 0.7319 \\
\hline Dwelling: some renovation needed & 0.2853 & 0.2799 & 0.2497 \\
\hline Dwelling: full renovation needed & 0.0250 & 0.0263 & 0.0184 \\
\hline Living area & 105.1393 & 98.0717 & 107.6911 \\
\hline Number of persons in household & 2.3319 & 2.3510 & 2.4714 \\
\hline Person needing care in household & 0.0477 & 0.0348 & 0.0454 \\
\hline No children in household & 0.7877 & 0.7651 & 0.7540 \\
\hline Family status: married & 0.5571 & 0.5541 & 0.5804 \\
\hline Family status: single & 0.2278 & 0.2465 & 0.2319 \\
\hline Family status: divorced & 0.0846 & 0.1077 & 0.0790 \\
\hline
\end{tabular}


TABLE A2

Continued

\begin{tabular}{|c|c|c|c|}
\hline 2011 & Protestants & Non-Protestant & Catholic \\
\hline Family status: widowed & 0.1127 & 0.0689 & 0.0880 \\
\hline Family status: married but separated & 0.0179 & 0.0229 & 0.0207 \\
\hline Partnership & 0.7267 & 0.7420 & 0.7433 \\
\hline Doctor visits & 2.7289 & 2.4600 & 2.4518 \\
\hline Disability & 0.1494 & 0.1432 & 0.1403 \\
\hline Hospital stay & 0.1419 & 0.1290 & 0.1231 \\
\hline Recently married & 0.0124 & 0.0111 & 0.0107 \\
\hline Recently moved together with partner & 0.0192 & 0.0135 & 0.0139 \\
\hline Recently divorced & 0.0096 & 0.0060 & 0.0052 \\
\hline Recently separated from partner & 0.0136 & 0.0172 & 0.0159 \\
\hline Recently experienced death of partner & 0.0056 & 0.0037 & 0.0046 \\
\hline Recently had a child & 0.0201 & 0.0181 & 0.0152 \\
\hline Extraversion & 4.7552 & 4.7149 & 4.6809 \\
\hline Agreeableness & 5.4669 & 5.4157 & 5.4878 \\
\hline Conscientiousness & 5.8215 & 5.8319 & 5.8517 \\
\hline Neuroticism & 3.8936 & 3.8509 & 3.8673 \\
\hline Openness & 4.3940 & 4.3506 & 4.2995 \\
\hline Year in the panel & 13.1116 & 13.6459 & 13.5415 \\
\hline Oral interview with paper and pencil & 0.1799 & 0.1958 & 0.2046 \\
\hline Oral interview with computer assistance & 0.2816 & 0.2433 & 0.2501 \\
\hline Self-written with interviewer presence & 0.0191 & 0.0246 & 0.0247 \\
\hline Partly oral, partly self-written interview & 0.0315 & 0.0254 & 0.0222 \\
\hline Self-written without interviewer presence & 0.1728 & 0.2036 & 0.2136 \\
\hline Self-written and sent via mail & 0.3151 & 0.3073 & 0.2849 \\
\hline Day of the interview: Monday & 0.1785 & 0.1865 & 0.1726 \\
\hline Day of the interview: Tuesday & 0.1658 & 0.1670 & 0.1746 \\
\hline Day of the interview: Wednesday & 0.2040 & 0.1917 & 0.1761 \\
\hline Day of the interview: Thursday & 0.1706 & 0.1595 & 0.1711 \\
\hline Day of the interview: Friday & 0.1431 & 0.1370 & 0.1359 \\
\hline Day of the interview: Saturday & 0.0999 & 0.1046 & 0.1168 \\
\hline Day of the interview: Sunday & 0.0381 & 0.0537 & 0.0529 \\
\hline Interview month: February & 0.3502 & 0.3232 & 0.3139 \\
\hline Interview month: March & 0.3094 & 0.3317 & 0.3127 \\
\hline Interview month: April & 0.1512 & 0.1614 & 0.1685 \\
\hline Interview month: May & 0.0932 & 0.0861 & 0.0961 \\
\hline Interview month: June & 0.0510 & 0.0519 & 0.0568 \\
\hline Interview month: July & 0.0337 & 0.0334 & 0.0407 \\
\hline Interview month: August & 0.0113 & 0.0125 & 0.0113 \\
\hline Regional exports ( 1,000 EUR/employee $)$ & 113.6571 & 115.1877 & 119.3249 \\
\hline Regional GDP (1,000 EUR/pop) & 31.7085 & 31.3792 & 33.4781 \\
\hline Reg: constr. permits new apartments (per 1,000 pop) & 2.2903 & 2.4541 & 2.7450 \\
\hline Reg: new apartments (per 1,000 existing apartments) & 3.7985 & 4.0528 & 4.6988 \\
\hline Reg: newly constructed apartments (per 1,000 pop) & 1.8462 & 1.9733 & 2.2341 \\
\hline Regional share foreigners $\%$ & 8.9079 & 8.8118 & 9.8756 \\
\hline Regional unemployment rate \% & 7.1132 & 7.3610 & 5.8387 \\
\hline Regional unemployment rate foreigners \% & 8.1472 & 7.8847 & 7.0469 \\
\hline Observations & 4,272 & 8,246 & 3,426 \\
\hline
\end{tabular}

TABLE A3

Monthly Distribution of Religious Denomination

\begin{tabular}{lcccc}
\hline & Protestants & Non-Protestant & Catholic & Obs \\
\hline Interview month: February & 0.3612 & 0.6388 & 0.2607 & 4,169 \\
Interview month: March & 0.321 & 0.679 & 0.2671 & 4,140 \\
Interview month: April & 0.3102 & 0.6898 & 0.3 & 1,970 \\
Interview month: May & 0.3918 & 0.6082 & 0.2952 & 1,118 \\
Interview month: June & 0.3254 & 0.6746 & 0.2938 & 633 \\
Interview month: July & 0.3835 & 0.6165 & 0.2784 & 352 \\
Interview month: August & 0.3456 & 0.6544 & 0.2059 & 136 \\
\hline
\end{tabular}


TABLE A4

Full Output First Stage

\begin{tabular}{|c|c|c|}
\hline Variable & Coefficient & Std. Err. \\
\hline News & $0.155^{* * *}$ & $(0.037)$ \\
\hline Female & $-0.034 * *$ & $(0.016)$ \\
\hline Direct migration background & $-0.084^{* *}$ & $(0.035)$ \\
\hline Indirect migration background & -0.001 & $(0.034)$ \\
\hline Age & 0.025 & $(0.015)$ \\
\hline Age squared & -0.000 & $(0.000)$ \\
\hline Age cube & 0.000 & $(0.000)$ \\
\hline German nationality & 0.016 & $(0.051)$ \\
\hline Turkish nationality & -0.017 & $(0.090)$ \\
\hline Italian nationality & -0.072 & $(0.112)$ \\
\hline Greek nationality & 0.241 & $(0.162)$ \\
\hline Secondary education & 0.029 & $(0.034)$ \\
\hline Tertiary education & 0.068 & $(0.044)$ \\
\hline Education years & $-0.127 * * *$ & $(0.035)$ \\
\hline Education years squared & $0.003^{* * *}$ & $(0.001)$ \\
\hline Full-time employment & $0.102^{* *}$ & $(0.049)$ \\
\hline Regular part-time employment & $0.103^{* * *}$ & $(0.051)$ \\
\hline Marginal, irregular part-time employment & $0.103^{* *}$ & $(0.053)$ \\
\hline Out of labor force & $0.083^{*}$ & $(0.045)$ \\
\hline Registered as unemployed & 0.009 & $(0.045)$ \\
\hline Self-employed & 0.015 & $(0.030)$ \\
\hline Retired & 0.029 & $(0.038)$ \\
\hline Log equalized real income & $-0.108^{* * *}$ & $(0.020)$ \\
\hline Owner of dwelling & $-0.042 * *$ & $(0.020)$ \\
\hline Dwelling needs some renovation & -0.005 & $(0.016)$ \\
\hline Dwelling needs full renovation & -0.030 & $(0.048)$ \\
\hline Living area & $0.001^{* *}$ & $(0.001)$ \\
\hline Living area squared & $-0.000^{*}$ & $(0.000)$ \\
\hline Number of persons in household & 0.011 & $(0.010)$ \\
\hline Person needing care in household & $-0.080^{* *}$ & $(0.038)$ \\
\hline No children in household & $0.055^{* * *}$ & $(0.023)$ \\
\hline Married & -0.010 & $(0.028)$ \\
\hline Divorced & 0.043 & $(0.037)$ \\
\hline Widowed & 0.043 & $(0.052)$ \\
\hline Separated & $-0.107 * *$ & $(0.048)$ \\
\hline Partnership & 0.031 & $(0.025)$ \\
\hline Number of doctor visits & $0.005 * *$ & $(0.002)$ \\
\hline Disability & $0.043 *$ & $(0.026)$ \\
\hline Hospital stay & 0.003 & $(0.025)$ \\
\hline Recently married & 0.056 & $(0.060)$ \\
\hline Recently moved together with partner & -0.032 & $(0.049)$ \\
\hline Recently divorced & 0.140 & $(0.088)$ \\
\hline Recently separated from partner & $0.111 *$ & $(0.056)$ \\
\hline Recently experienced death of partner & 0.183 & $(0.180)$ \\
\hline Recently had a child & -0.058 & $(0.045)$ \\
\hline Regional exports & 0.000 & $(0.000)$ \\
\hline Regional GDP & 0.002 & $(0.002)$ \\
\hline Regional constr. permits new apartments & -0.009 & $(0.029)$ \\
\hline Regional share new apartments & 0.034 & $(0.041)$ \\
\hline Regional newly constructed apartments & -0.084 & $(0.092)$ \\
\hline Regional share foreigners \% & -0.005 & $(0.005)$ \\
\hline Regional unemployment rate \% & $0.020 * *$ & $(0.009)$ \\
\hline Regional unemployment rate foreigners \% & -0.000 & $(0.001)$ \\
\hline Self-written questionnaire and sent via mail & 0.022 & $(0.029)$ \\
\hline Partly oral, partly self-written interview & -0.057 & $(0.035)$ \\
\hline Self-written without interviewer presence & 0.018 & $(0.028)$ \\
\hline Protestant & 0.025 & $(0.020)$ \\
\hline Other religion & 0.021 & $(0.045)$ \\
\hline No denomination & -0.006 & $(0.021)$ \\
\hline Federal state dummies & Yes & \\
\hline Years in panel dummies & Yes & \\
\hline Observations & 6,436 & \\
\hline$R^{2}$ & 0.125 & \\
\hline
\end{tabular}

Notes: Dependent variable is being very concerned about the euro. Further controls include variables for federal state (15) and year in the panel (26). Robust standard errors are in parentheses. Survey weights are used. SOEP data from 2011 and LexisNexis data are used. ${ }^{* * *} p<.01,{ }^{* *} p<.05,{ }^{*} p<.1$. 
TABLE A5

Reduced Form and First Stage-Full Sample

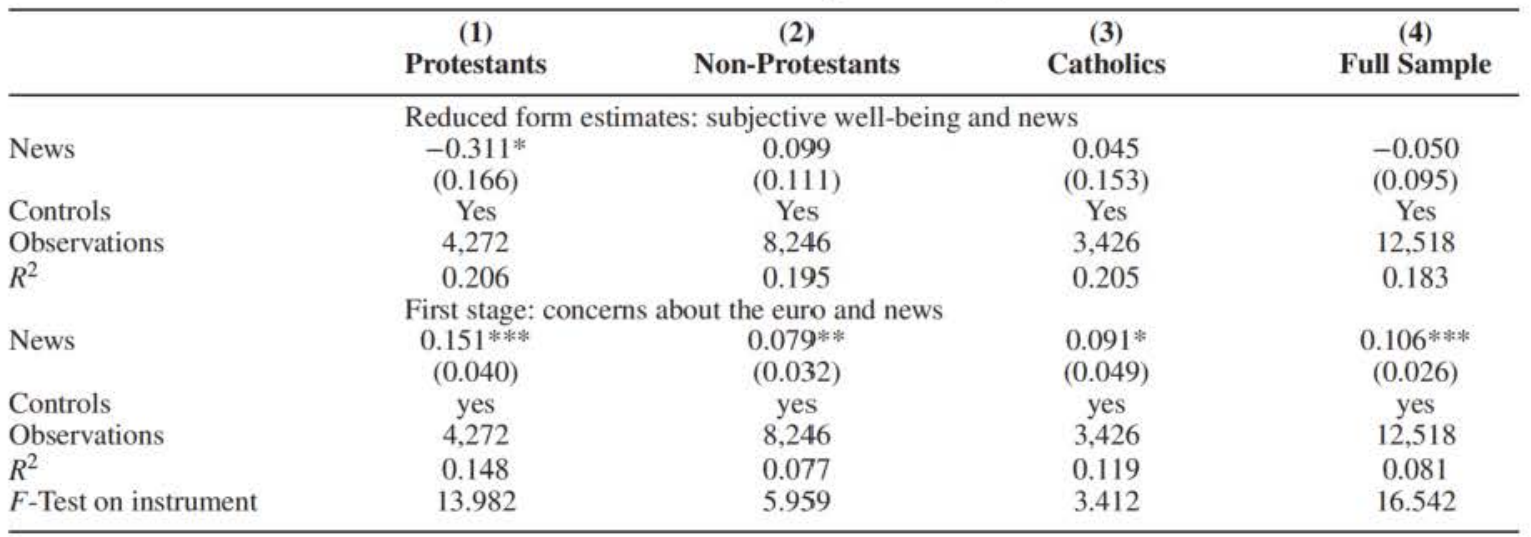

Notes: Dependent variable in upper panel is life satisfaction on a 0 to 10 scale. Dependent variable in lower panel is being very concerned about the euro. Control variables are the same as in Table 4, except for Big Five personality measures, which are not included. Robust standard errors are in parentheses.

$* * * p<.01, * * p<.05, * p<.1$.

TABLE A6

Second Stage-Full Sample

\begin{tabular}{|c|c|c|c|c|c|c|c|c|}
\hline & (1) & (2) & (3) & (4) & (5) & (6) & (7) & (8) \\
\hline & \multicolumn{2}{|c|}{ Protestants } & \multicolumn{2}{|c|}{ Non-Protestants } & \multicolumn{2}{|c|}{ Catholics } & \multicolumn{2}{|c|}{ All Denominations } \\
\hline & IV & OLS & IV & OLS & IV & OLS & IV & OLS \\
\hline \multirow[b]{2}{*}{ Euro concerns } & \multicolumn{2}{|c|}{ All survey methods } & & & & & & \\
\hline & $-2.061^{*}$ & -0.490 *** & 1.256 & -0.267 水水* & 0.492 & $-0.285^{* * * *} *{ }^{*}$ & -0.476 & $\begin{array}{c}-0.343 * * * \\
(0.057)\end{array}$ \\
\hline Controls & Yes & Yes & Yes & Yes & Yes & Yes & Yes & Yes \\
\hline Observations & 4,272 & 4,272 & 8,246 & 8,246 & 3,426 & 3,426 & 12,518 & 12.518 \\
\hline$R^{2}$ & 0.106 & 0.216 & 0.081 & 0.198 & 0.179 & 0.209 & 0.187 & 0.188 \\
\hline
\end{tabular}

Notes: Dependent variable is life satisfaction on a 0 to 10 scale. Control variables are the same as in Table 4, except for Big Five personality measures, which are not included. Robust standard errors are in parentheses.

**** $p<.01,{ }^{* * *} p<.05,{ }^{*} p<.1$. 
TABLE A7

Full Output Second Stage

\begin{tabular}{|c|c|c|}
\hline Variable & Coefficient & Std. Err. \\
\hline Concerned about the euro & $-1.997^{* *}$ & $(0.892)$ \\
\hline Female & -0.026 & $(0.077)$ \\
\hline $\begin{array}{l}\text { Direct migration } \\
\text { background }\end{array}$ & -0.092 & $(0.188)$ \\
\hline $\begin{array}{l}\text { Indirect migration } \\
\text { background }\end{array}$ & 0.119 & $(0.137)$ \\
\hline Age & -0.028 & $(0.069)$ \\
\hline Age squared & -0.000 & $(0.001)$ \\
\hline Age cube & 0.000 & $(0.000)$ \\
\hline German nationality & 0.005 & $(0.259)$ \\
\hline Turkish nationality & 0.420 & $(0.425)$ \\
\hline Italian nationality & 0.124 & $(0.467)$ \\
\hline Greek nationality & $2.201 *$ & $(1.140)$ \\
\hline Secondary education & 0.077 & $(0.133)$ \\
\hline Tertiary education & $0.446^{* * *}$ & $(0.194)$ \\
\hline Education years & 0.020 & $(0.179)$ \\
\hline Education years squared & -0.003 & $(0.006)$ \\
\hline Full-time employment & -0.043 & $(0.248)$ \\
\hline $\begin{array}{l}\text { Regular part-time } \\
\text { employment }\end{array}$ & 0.148 & $(0.261)$ \\
\hline $\begin{array}{l}\text { Marginal, irregular } \\
\text { part-time employment }\end{array}$ & -0.051 & $(0.272)$ \\
\hline Out of labor force & 0.115 & $(0.260)$ \\
\hline Registered as unemployed & $-0.728 * * *$ & $(0.205)$ \\
\hline Self-employed & 0.081 & $(0.125)$ \\
\hline Retired & 0.172 & $(0.180)$ \\
\hline $\begin{array}{l}\text { Log equalized real } \\
\text { income }\end{array}$ & $0.328 * *$ & $(0.137)$ \\
\hline Owner of dwelling & -0.095 & $(0.092)$ \\
\hline $\begin{array}{l}\text { Dwelling needs some } \\
\text { renovation }\end{array}$ & $-0.434 * * *$ & $(0.071)$ \\
\hline $\begin{array}{l}\text { Dwelling needs full } \\
\text { renovation }\end{array}$ & $-0.809 * * *$ & $(0.222)$ \\
\hline Living area & 0.005 & $(0.003)$ \\
\hline Living area squared & -0.000 & $(0.000)$ \\
\hline $\begin{array}{l}\text { Number of persons in } \\
\text { household }\end{array}$ & 0.046 & $(0.042)$ \\
\hline $\begin{array}{l}\text { Person needing care in } \\
\text { household }\end{array}$ & -0.792 **** & $(0.191)$ \\
\hline No children in household & $0.231 *$ & $(0.120)$ \\
\hline Married & 0.178 & $(0.121)$ \\
\hline Divorced & 0.186 & $(0.171)$ \\
\hline Widowed & $0.505^{* *}$ & $(0.220)$ \\
\hline Separated & 0.286 & $(0.263)$ \\
\hline Partnership & $0.613^{* * * *}$ & $(0.113)$ \\
\hline Number of doctor visits & $-0.061^{* * *}$ & $(0.010)$ \\
\hline Disability & -0.105 & $(0.117)$ \\
\hline Hospital stay & $-0.253^{* *}$ & $(0.112)$ \\
\hline Recently married & -0.207 & $(0.325)$ \\
\hline $\begin{array}{l}\text { Recently moved together } \\
\text { with partner }\end{array}$ & -0.006 & $(0.192)$ \\
\hline Recently divorced & $0.767^{* * *}$ & $(0.370)$ \\
\hline $\begin{array}{l}\text { Recently separated from } \\
\text { partner }\end{array}$ & -0.115 & $(0.284)$ \\
\hline $\begin{array}{l}\text { Recently experienced } \\
\text { death of partner }\end{array}$ & $-2.067^{* *}$ & $(1.013)$ \\
\hline Recently had a child & $0.560^{* * *}$ & $(0.177)$ \\
\hline Regional exports & 0.000 & $(0.001)$ \\
\hline Regional GDP & 0.008 & $(0.010)$ \\
\hline $\begin{array}{l}\text { Regional constr. permits } \\
\text { new apartments }\end{array}$ & -0.037 & $(0.125)$ \\
\hline $\begin{array}{l}\text { Regional share new } \\
\text { apartments }\end{array}$ & -0.262 & $(0.185)$ \\
\hline
\end{tabular}

TABLE A7

Continued

\begin{tabular}{lcc}
\hline Variable & Coefficient & Std. Err. \\
\hline $\begin{array}{l}\text { Regional newly } \\
\quad \text { constructed apartments } \\
\text { Regional share foreigners }\end{array}$ & $0.709^{*}$ & $(0.455)$ \\
$\quad \%$ & $-0.039^{*}$ & $(0.022)$ \\
$\begin{array}{l}\text { Regional unemployment } \\
\quad \text { rate \% }\end{array}$ & $0.074^{*}$ & $(0.044)$ \\
$\begin{array}{l}\text { Regional unemployment } \\
\quad \text { rate foreigners \% }\end{array}$ & 0.003 & $(0.003)$ \\
$\begin{array}{l}\text { Self-written questionnaire } \\
\quad \text { and sent via mail }\end{array}$ & -0.052 & $(0.128)$ \\
$\begin{array}{l}\text { Partly oral, partly } \\
\quad \text { self-written interview }\end{array}$ & 0.086 & $(0.164)$ \\
$\begin{array}{l}\text { Self-written without } \\
\quad \text { interviewer presence }\end{array}$ & -0.071 & $(0.123)$ \\
$\begin{array}{l}\text { Protestant } \\
\text { Other religion }\end{array}$ & -0.102 & $(0.089)$ \\
$\begin{array}{l}\text { No denomination } \\
\text { Federal state dummies }\end{array}$ & $-0.542^{* * *}$ & $(0.231)$ \\
Years in panel dummies & $-0.193^{* *}$ & $(0.097)$ \\
$\begin{array}{l}\text { Observations } \\
R^{2}\end{array}$ & Yes & \\
\hline
\end{tabular}

Notes: Dependent variable is life satisfaction on a 0 to 10 scale. Further controls include variables for federal state (15) and year in the panel (26). Robust standard errors are in parentheses. Survey weights are used. SOEP data from 2011 and LexisNexis data are used.

*** $p<.01,{ }^{* *} p<.05,{ }^{*} p<.1$.

\section{REFERENCES}

Ankenbrand, H. "Der Protestant." Frankfurter Allgemeine Zeitung, December 14, 2013.

- "Christliche Alternative für Deutschland" Frankfurter Allgemeine Zeitung, March 10, 2014.

Arruñada, B. "Specialization and Rent-Seeking in Moral Enforcement: The Case of Confession." Journal for the Scientific Study of Religion, 48(3), 2009, 443-61. - "Protestants and Catholics: Similar Work Ethic, Different Social Ethic." Economic Journal, 120(547), 2010, 890-918.

Barro, R. J., and R. M. McCleary. "Which Countries Have State Religions?" Quarterly Journal of Economics, 120(4), 2005, 1331-70.

Becker, S. O., and L. Woessmann. "Was Weber Wrong? A Human Capital Theory of Protestant Economic History." Quarterly Journal of Economics, 124(2), 2009, 531-96.

. "Social Cohesion, Religious Beliefs, and the Effect of Protestantism on Suicide." Discussion Paper, 2015.

Becker, S. O., S. Pfaff, and J. Rubin. "Causes and Consequences of the Protestant Reformation." Explorations in Economic History, 62, 2016, 1-25.

Boffa, F., A. Piolatto, and G. A. M. Ponzetto. "Political Centralization and Political Accountability." Ouarterly Journal of Economics, 131(1), 2016, 381-422.

Bowlby, C. "The Eurozone's Religious Faultline." BBC News Magazine, July 19, 2012. Accessed May 24, 2017. http://www.bbc.com/news/magazine-18789154.

Cantoni, D. "Adopting a New Religion: The Case of Protestantism in 16th Century Germany." Economic Journal, 122(560), 2012, 502-31.

"The Economic Effects of the Protestant Reformation: Testing the Weber Hypothesis in the German 
Lands." Journal of the European Economic Association, 13(4), 2015, 561-98.

Chadi, A. "Concerns about the Euro and Happiness in Germany during Times of Crisis." European Journal of Political Economy, 40, 2015, 126-46.

Colvin, C. L. and M. McCracken. "Work Ethic, Social Ethic, No Ethic: Measuring the Economic Values of Modern Christians." Journal of Applied Econometrics, Epub ahead of print, August 30, 2016. doi: 10.1002/jae.2543.

Conti, G., and S. Pudney. "Survey Design and the Analysis of Satisfaction." Review of Economics and Statistics, 93(3), 2011, 1087-93.

Deaton, A. "The Financial Crisis and the Well-being of Americans." Oxford Economic Papers, 64(1), 2012, 1-26.

Dustmann, C., B. Fitzenberger, U. Schönberg, and A. Spitz-Oener. "From Sick Man of Europe to Economic Superstar: Germany's Resurgent Economy." Journal of Economic Perspectives, 28(1), 2014, 167-88.

Ehrmann, M., and P. Tzamourani. "Memories of High Inflation." European Journal of Political Economy, 28(2), 2012, 174-91.

Ferrer-i Carbonell, A., and P. Frijters. "How Important Is Methodology for the Estimates of the Determinants of Happiness?" Economic Journal, 114(497), 2004, 641-59.

Filistrucchi, L., and J. Prüfer "Faithful Strategies: How Religion Shapes Nonprofit Management." CentER Discussion Paper, No. 52, 2013

Franck, R. "Economic Growth and the Separation of Church and State: The French Case." Economic Inquiry, 48(4), 2010, 841-59.

Giuliano, P., and A. Spilimbergo. "Growing Up in a Recession." Review of Economic Studies, 81(2), 2014, 787-817.

Glaeser, E. L., and B. I. Sacerdote. "Education and Religion." Journal of Human Capital, 2(2), 2008, 188-215.

Goebel, J., C. Krekel, T. Tiefenbach, and N. R. Ziebarth. "How Natural Disasters Can Affect Environmental Concerns, Risk Aversion, and Even Politics: Evidence from Fukushima and Three European Countries." Journal of Population Economics, 4, 2015, 1137-80.

Gruber, J. H. "Religious Market Structure, Religious Participation, and Outcomes: Is Religion Good for You?" The B.E. Journal of Economic Analysis \& Policy, 5(1), 2005 , $1-32$.

Guiso, L., P. Sapienza, and L. Zingales. "People's Opium? Religion and Economic Attitudes." Journal of Monetary Economics, 50(1), 2003, 225-82.

— "Does Culture Affect Economic Outcomes?" Journal of Economic Perspectives, 20(2), 2006, 23-48.

Guiso, L., H. Herrera, and M. Morelli. "Cultural Differences and Institutional Integration." Journal of International Economics, 99, 2016a, S97-113.

Guiso, L., P. Sapienza, and L. Zingales. "Long Term Persistence." Journal of the European Economic Association, 14(6), 2016b, 1401-36.

Heineck, G. "The Determinants of Church Attendance and Religious Human Capital in Germany: Evidence from Panel Data." Discussion Paper, 2001.

Iannaccone, L. R. "Introduction to the Economics of Religion." Journal of Economic Literature, 36(3), 1998, $1465-96$.

Iannaccone, L. R., and E. Berman. "The Economics of Religion," in The New Palgrave Dictionary of Economics, 2nd ed., edited by S. N. Durlauf and L. E. Blume. Basingstoke, England: Palgrave Macmillan, 2008.

Imbens, G. W., and J. D. Angrist. "Identification and Estimation of Local Average Treatment Effects." Economet rica, 62(2), 1994, 467-75.
Janus, A. L. "The Influence of Social Desirability Pressures on Expressed Immigration Attitudes." Social Science Quarterly, 91(4), 2010, 928-46.

Kauder, B., N. Potrafke, and M. Riem. "Do Parties Punish MPs for Voting Against the Party Line?" Discussion paper, Ifo Institute, Ifo Center for Public Finance and Political Economy, 2015.

La Porta, R., F. Lopez-de Silanes, A. Shleifer, and R. W. Vishny. "Trust in Large Organizations." American Economic Review, 87(2), 1997, 333-38.

Luna-Arocas, R., G. Guzman, I. Quintanilla, and M. Farhangmehr. "The Euro and European Identity: The Spanish and Portuguese Case." Journal of Economic Psychology, 22(4), 2001, 441-60.

Malmendier, U., and S. Nagel. "Depression Babies: Do Macroeconomic Experiences Affect Risk Taking?" Quarterly Journal of Economics, 126(1), 2011, 373-416.

Metcalfe, R., N. Powdthavee, and P. Dolan. "Destruction and Distress: Using a Quasi-Experiment to Show the Effects of the September 11 Attacks on Mental Well-Being in the United Kingdom." Economic Journal, 121(550), 2011, F81-103.

Mian, A., A. Sufi, and F. Trebbi. "The Political Economy of the US Mortgage Default Crisis." American Economic Review, 100(5), 2010, 1967-98.

Montagnoli, A., and M. Moro. "Everybody Hurts: Banking Crises and Individual Wellbeing." Working Paper, Sheffield University, 2014.

Nelsen, B. F., and J. L. Guth. "Roman Catholicism and the Founding of Europe: How Catholics Shaped the European Communities." Annual Meeting of the American Political Science Association, Philadelphia, Pennsylvania, 2003, 28-31

Nunn, N. "The Importance of History for Economic Development." Annual Review of Economics, 1(1), 2009, $65-92$

Priluck, J. "The Two Europes." Slate, February 6, 2015 Accessed May 24, 2017. http://www.slate.com/ articles/business/moneybox/2015/02/greece_austerity_ eurozone leaders won_t_back_off_because_of_the vastly_different.html.

Renneboog, L., and C. Spaenjers. "Religion, Economic Attitudes, and Household Finance." Oxford Economic Papers, 64(1), 2012, 103-27.

Schüller, S. "The 9/11 Conservative Shift." Economics Letters, $135,2015,80-4$.

. "The Effects of 9/11 on Attitudes toward Immigration and the Moderating Role of Education." Kyklos, 69(4), 2016, 604-32.

Sieberer, U. "Behavioral Consequences of Mixed Electoral Systems: Deviating Voting Behavior of District and List MPs in the German Bundestag." Electoral Studies, 29(3), 2010, 484-96.

SOEP. "Socio-Economic Panel (SOEP), Data for Years 1984-2012," Version 29, 2013 https://doi.org/10.5684/soep.v29.

Spenkuch, J. L. "Religion and Work: Micro Evidence from Contemporary Germany." Journal of Economic Behavior \& Organization, 135, 2017, 193-214.

Spenkuch, J. L., and P. Tillmann. "Special Interests at the Ballot Box? Religion and the Electoral Success of the Nazis." American Journal of Political Science, forthcoming.

Staiger, D., and J. H. Stock. "Instrumental Variables Regression with Weak Instruments." Econometrica, 65(3), 1997, 557-86.

Stock, J. H., and M. Yogo. "Testing for Weak Instruments in Linear IV Regression," in Identification and Inference for Econometric Models: Essays in Honor of Thomas Rothenberg, edited by D. W. K. Andrews, and J. H. 
Stock. New York: Cambridge University Press, 2005, $80-108$.

Strulik, H. "Secularization and Long-Run Economic Growth." Economic Inquiry, 54(1), 2016, 177-200.

Stulz, R. M., and R. Williamson. "Culture, Openness, and Finance." Journal of Financial Economics, 70(3), 2003, 313-49.

Traunmüller, R. "Moral Communities? Religion as a Source of Social Trust in a Multilevel Analysis of 97 German Regions." European Sociological Review, 27(3), 2011, 346-63.

Van Hoorn, A., and R. Maseland. "Does a Protestant Work Ethic Exist? Evidence from the Well-being Effect of Unemployment." Journal of Economic Behavior \& Organization, 91(C), 2013, 1-12.

Voigtländer, N., and H.-J. Voth. "Persecution Perpetuated: The Medieval Origins of Anti-Semitic Violence in Nazi Germany." Quarterly Journal of Economics, 127(3), 2012, 1339-92.

Vollaard, H. "Protestantism and Euro-scepticism in the Netherlands." Perspectives on European Politics and Society, 7(3), 2006, 276-97.
Wagner, G. G., and J.-P. Schraepler. "Das Verhalten von Interviewern-Darstellung und ausgewählte Analysen am Beispiel des Interviewer-Panels des Soziooekonomischen Panels." Allgemeines Statistisches Archiv, 85(1), 2001, 45-66.

Wagner, G. G., J. R. Frick, and J. Schupp. "The German Socio-Economic Panel Study (SOEP) - Scope, Evolution and Enhancements." Schmollers Jahrbuch : Journal of Applied Social Science Studies / Zeitschrift für Wirtschafts- und Sozialwissenschaften, 127(1), 2007, 139-69.

Weber, M. "Die protestantische Ethik und der 'Geist' des Kapitalismus," in Archiv für Sozialwissenschaft und Sozialpolitik 20, 1904/1905, 1-54 and 21, 1-110, reprinted in Gesammelte Aufsätze zur Religionssoziologie, edited by J. C. B. Mohr. Tübingen, Germany: Paul Siebeck, 17-206, 1920.

Wunder, C., J. Schwarze, G. Krug, and B. Herzog. "Welfare Effects of the Euro Cash Changeover." European Journal of Political Economy, 24(3), 2008, 571-86. 